\title{
Pemberdayaan Masyarakat dan Mahasiswa dalam Mewujudkan Desa Mandiri melalui Pemanfaatan Lahan dan Sampah di Kecamatan Tanjung Palas Utara, Kabupaten Bulungan
}

\author{
Community and Student Empowerment in Realizing Independent Villages with Land and \\ Waste Utilization, North Tanjung Palas District, Bulungan Regency
}

\begin{abstract}
Arif Rohman ${ }^{*}$
Dewi Nurvianti ${ }^{2}$

Sapriani $^{3}$

1Department of Criminal Law, Universitas Borneo Tarakan, Tarakan, North Kalimantan, Indonesia

2Department of International Law, Universitas Borneo Tarakan, Tarakan, North Kalimantan, Indonesia

32Department of Constitutional Law, Universitas Borneo Tarakan, Tarakan, North Kalimantan, Indonesia
\end{abstract}

email: arifrohman_ubt@yahoo.com

Kata Kunci

Desa mandiri

Pemanfaatan lahan

Pemberdayaan masyarakat

Keywords:

Independent village

Land use

Community development

Received: February 2021

Accepted: September 2021

Published: October 2021

\begin{abstract}
Abstrak
Salah satu bentuk sumbangsih keberadaan suatu perguruan tinggi adalah pelaksanaan kegiatan pengabdian kepada masyarakat di wilayah sekitar dimana perguruan tinggi berada. Kehidupan yang dinamis menjadikan masyarakat membutuhkan regulasi dan membutuhkan solusi dalam memecahkan masalah. Solusi yang ditawarkan dalan pengabdian ini adalah pemanfaatan lahan untuk tanaman hidroponik yang dilaksanakan di desa ardi mulyo dan pemanfaatan sampah rumah tangga sebagai bahan bakar. Metode yang digunakan dalam PKM ini adalah partisipasi masyarakat dan mahasiswa, karena konsep pelaksanaan PKM adalah pemberdayaan masyarakat. Hasil pelaksanaan PKM menunjukkan bahwa kegiatan yang dilaksanakan sangat bermanfaat bagi masyarakat, karena konsep yang dibngun adalah dalam rangka mewujudkan desa mandiri baik untuk kebutuhan hidup berupa sayuran maupun kebutuhan pengganti minyak tanah dan gas melalui penyulingan limbah botol plastik. Metode yang digunakan dalam pelaksanaan PKM ini adalah partisipaotis, yakni keterlibatan masyarakat dan mahasiswa. Metode ini digunakan karena PKM yang dilaksanakan oleh Tim berkaitan dengan pemberdayaan, sehingga peran tim hanya penyaji dan pemantau untuk keberlanjutan program yang telah dilaksanakan. Hasil pelaksanaan kegiatan terlihat bahwa masyarakat sangat antusias terhadap kegiatan yang dilakukan Tim, hal ini dapat dilihat partisipasi masyarakat tidak hanya dukungan semata, dan program yang dilaksanakan juga tepat sasaran dan tepat guna sehingga kemandirian desa akan terbentuk dengan penerapan-penerapan program yang sangat sederhana.
\end{abstract}

\begin{abstract}
One form of contribution to the existence of a tertiary institution is the implementation of community service in the area where the college is located. A dynamic life makes people need regulation and needs solutions in solving problems. The solution offered in this service is using land for hydroponic plants carried out in the Ardi Mulyo Village and the use of household waste as fuel. The method used is the participation of the community and students because the concept of implementing PKM is community empowerment. The implementation results show that the activities carried out are very beneficial for the community because the concept used is to realize an independent village for living needs in the form of vegetables and the demand for substitutes for kerosene and gas through plastic bottles waste refining. The method used in implementing this PKM is participatory, namely the involvement of the community and students. This method is used because the PKM carried out by the team relates to empowerment. Hence, the role is to present and monitor for the sustainability of the programs that have been implemented. The results of the implementation of the activities show that the community is very enthusiastic about the activities carried out, this can be seen by the community's participation, and the programs implemented are also right on target and effective so that the independence of the village will be formed with straightforward program implementations.
\end{abstract}




\section{PENDAHULUAN}

Kecamatan Tanjung Palas Utara merupakan salah satu kecamatan yang ada di Kabupaten Bulungan Provinsi Kalimantan Utara. Adapun batas wilayah Kecamatan Tanjung Palas Utara bagian utara berbatasan dengan Kecamatan Sekatak, Bagian Selatan Kecamatan Tanjung Palas Barat, bagian barat berbatasan dengan Kecamatan Peso Hilir dan bagian timur berbatasan dengan Kecamatan Tanjung Palas Tengah. Jumlah penduduk yang mendiami wilayah Kecamatan Tanjung Palas Utara berjumlah 8.418 Jiwa, dengan 2.151 KK, meliputi 4.495 jiwa laki-laki dan perempuan 3.923 jiwa dengan tingkat kepadatan mencapai 10,44 jiwa/ $\mathrm{km}^{2}$ dan tingkat rata-rata penduduk/keluarga 3,91 jiwa. Tujuan pembentukan Kecamatan Tanjung Palas Utara adalah untuk meningkatkan penyelenggaraan pemerintahan, pelaksanaan pembangunan dan pembinaan kemasyarakatan yang berguna untuk menjamin perkembangan dan kemajuan desa-desa diwilayah Kecamatan Tanjung Palas Utara.

Pembentukan kecamatan tersebut tidak serta merta dibentuk, akan tetapi hasil kesepakatan dan usulan masyarakat desa-desa yang berada di wilayah Kecamatan Tanjung Palas Utara, mengingat perkembangan transmigran semakin bertambah penduduknya, tetapi tidak dibarengi dengan perkembangan potensi yang ada di wilayah tersebut (Yusup \& Giyarsih, 2015). Sehinnga diperlukan upaya untuk mengembangkan masyarakat, karena persepsi masyarakat yang telah lama tinggal dikecamatan tersebut sudah beralih haluan, tidak hanya fokus pada pertanian, tetapi juga beranjak pada sektor lainnya.

Meskipun keberadaan Kecamatan Tanjung Palas Utara tidah jauh dari pusat pemerintahan Kabupaten Bulungan, tetapi proses pembangunan belum cukup untuk pemerataan pembangunan, dikarenakan akses jalan utama yang baru saja diperbaiki. Sehingga terlihat ketidak merataan pembangunan yang ada di Kabupaten Bulungan, seperti kebersihan sampah dan PDAM hanya berfokus pada ibu kota kabupaten saja. Padahal potensi sampah yang ada di setiap desa atau kelurahan pastiada, namun tidak tertangani dengan baik dan maksimal, serta keberadaan lahan kosong di setiap desa termasuk desadesa yang ada di Kecamatan Tanjung Palas Utara.

Pada dasarnya manusia hidup dan berkembang secara dimanis, karena kodrat manusia adalah mencapai kemakmuran dan keadilan (Helmi, 2015). Permasalahan mendesak yang ada di Kecamatan Tanjung Palas Utara belum maksimalnya pemanfaatan sampah dan lahan kosong, karena daerah ini merupakan salah satu pusat transmigrasi dan termasuk lama, maka perubahan konsep masyarakat terhadap transmigrasi sudah sedikit memudar, hal ini dapat dilihat dari proyeksi hasil pertanian yang tidak kunjung mencapai target dan tujuan utama dalam mengembangkan sektor pertanian. Adapun sektor pertanian yang dikembangkan di wilayah Kecamatan Tanjung Palas Utara antara lain: Padi, palawija, sayuran, padi sawah, padi ladang, jagung, ubi kayu, ubi jalar, kavang hijau, kedelai, buah-buahan dan kacang tanah (Badan Pusat Statistik Kabupaten Bulungan, 2020). Secara umum diketahui bahwa penataan daerah transmigrasi adanya lahan disekitar pemukiman atau rumah yang telah disediakan, namun belum dimanfaatkan masyakat secara maksimal, karena hanya berfokus pada pertanian atau padi sawah. Begitu juga dengan keberadaan sampah yang diproduksi oleh rumah tangga, sehingga perlu adanya perubahan konsep terhadap pemanfaatan sampah-sampah rumah tangga tersebut, karena tidak tertata dan termanfaatkan dengan baik (Susilowati \& Maulana, 2012).

\section{METODOLOGI}

Metode yang digunakan pada pelaksanaan kegiatan program kemitraan bagi masyarakat ini antara lain: 


\section{Pendekatan sosial}

Sasaran pendekatan sosial disini adalah pelibatan masyarakat baik orang tua, pemuda maupun pelajar setempat dan mahasiswa pelaksanaan. Kegiatan ini melibatkan mahasiswa pelaksanaa KKN dikarenakan PKM yang kami lakukan terintegrasi dengan pelaksanaan KKN dan dilaksanakan di salah satu desa binaan Universitas Borneo Tarakan. Pendekatan sosial ini dilakukan untuk melihat partisipasi masyarakat setempat pada pelaksanaan program-program yang telah disusun dan direncanakan. Perubahan sosial merupakan fenomena kehidupan yang dialami oleh setiap masyarakat dimanapun dan kapanpun. Setiap masyarakat manusia selama hidupnya pasti mengalami perubahan-perubahan dalam berbagai aspek kehidupannya, yang terjadi ditengah-tengah pergaulan (interaksi) antara sesama individu warga masyarakat, demikian pula antara masyarakat dengan lingkungan hidupnya.

Kehidupan masyarakat menjadi makin rasional, karena meluasnya pendidikan, serta meningkatnya orientasi komersil di kalangan warga masyarakat. Hubungan emosional mulai melemah, digeser oleh hubungan rasional. Kepentingan diri sendiri bersama dengan keluarga menjadi prioritas dalam kehidupan setiap keluarga. Orang-orang pun sudah mulai saling kurang memperhatikan kegiatankegiatan sehari-hari, dan akibatnya kontrol sosial langsung makin lemah. Banyak masalah-masalah yang timbul dikalangan masyarakat tidak lagi menjadi kepedulian umum di kalangan mereka (Suradi, 2013).

Ruang lingkup perubahan-perubahan sosial mencakup unsur-unsur kebudayaan, baik yang bersifat material maupun immaterial, dengan menekankan pada adanya pengaruh yang lebih besar pada unsur kebudayaan material dari pada unsur yang immaterial (Ariyani \& Nurcahyono, 2014). Sedangkan Menurut Selo Soemardjan, perubahan sosial adalah segala perubahanperubahan pada lembaga-lembaga kemasyarakatan di dalam suatu masyarakat, yang mempengaruhi sistem sosialnya, termasuk didalamnya nilai-nilai, sikap-sikap dan pola-pola prilaku diantara kelompok-kelompok masyarakat (Cahyono, 2016).

2. Persiapan

a. Pada tahap persiapan ini, yang dilakukan adalah memberikan pemahaman konsep desa mandiri kepada masyarakat dan mahasiswa dengan cara pendekatan sosial yakni pelibatan masyarakan dan mahasiswa dalam memanfaatkan lahan kosong di sekitar rumah, dan pemanfaatan sampah rumah tangga dijadikan sebagai bahan bakar pengganti minyak tanah atau gas.

b. Penyusunan dan pengumpulan bahan seperti surat menyurat, bahan-bahan pembuatan hidroponik (gelas plastik dan bibit sayuran), kaleng dan pipa besi.

3. Pelaksaan kegiatan

a. penetapan kegiatan pelaksanaan kegiatan ini ditetapkan sebagai wujud peran Universitas Borneo Tarakan sebagai kegiatan pengabdian pada masyarakat dalam mewujudkan desa mandiri melalui kegiatan pemanfaatan lahan untuk tanaman hidroponik dan pemanfaatan sampah rumah tangga untuk bahan bakar.

b. penetapan waktu waktu pelaksnaan kegiatan ini terbagi dalam waktu yang berbeda, yang pertama kegiatan pembuatan hidroponik dengan memanfatkan lahan kosong yang ada di Desa Ardi Mulyo. Sedangkan hari berikutnya pelaksanaan kegiatan 
pemanfaatan sampah rumah tangga menjadi bahan bakar dilaksanakan di Desa Panca Agung.

c. penetapan tempat

Adapun tempat pelaksanaan kegiatan yang pertama dilakukan di lahan kosong milik desa yang ada di sekitar kantor Desa Ardi Mulyo sebagai prioritas utama, sehingga masyakat dapat meniru dan membuat di pekarangan rumah masing-masing. Kegiatan kedua dilaksanakan di SDN 004 Tanjung Palas Utara.

d. penetapan orang yang terlibat

kegiatan pertama melibatkan unsur pemerintah Desa Ardi Mulyo, Masyarakat dan Mahasiswa. Kegiatan kedua melibatkan siswa-siswa SDN 004 Tanjung Palas Utara, Masyarakat dan Mahasiswa UBT.

e. Evaluasi Kegiatan dan Hasil

Pada tahap evaluasi, yang dilakukan oleh pelaksana kegiatan pengbdian kepada masyarakat adalah menata ulang hasil pelaksanaan kegiatan pertama dan kedua, baik bahan-bahan yang diperlukan atau peran masyarakat dan mahasiswa. Terlihat bahwa pada pelaksanaan kegiatan baik pertama maupun kedua cukup berhasil, karena dapat dilaksanakan oleh masyarakat meskipun butuh bahan yang harus aman untuk digunakan baik aman untuk manusia maupun untuk lingkungan.

Kegiatan pertama diteruskan oleh anggota pemerintahan Desa Ardi Mulyo, dan dapat dilakukan di pekarangan rumah masyarakat. Kegiatan kedua dapat dilaksanakan oleh masyarakat Desa Panca Agung bahkan dapat dilakukan oleh siswa-siswa Sekolah Dasar tetapi harus dalam pengawasan guru maupun orang tua.

\section{HASIL DAN PEMBAHASAN}

Pemberdayaan Masyarakat

Istilah masyarakat dalam Bahasa Indonesia sering merupakan terjemahaan dari Bahasa Inggris society dan community. Konsep masyarakat yang berasal dari society berbeda konsep dengan masyarakat yang bersumber dari community, karena dari perspektif sosiologi pengertian society berbeda dengan community. Konsep istilah masyarakat diterjemahkan dari kata atau konsep community, oleh karena itu istilah konsep masyarakat tersebut tidak rancu dan bermakna ganda (Nasdim, 2014).

Sedangkan istilah pemberdayaan berasal dari kata power yang bermakna kekuasaan atau keberdayaan (Baridi et al., 2007). Pemberdayaan menunjuk pada kemampuan orang. Khususnya kelompok rentan dan lemah sehingga mereka memiliki kekuatan atau kemampuan dalam:

1. memenuhi kebutuhan dasarnya sehingga mereka memiliki kebebasan (freedom), dalam arti bukan saja bebas mengemukakan pendapat, melainkan bebas dari kelaparan, bebas dari kebodohan, bebas dari kesakitan;

2. menjangkau sumber-sumber produktif yang memungkinkan mereka dapat meningkatkan pendapatannya dan memperoleh barang-barang dan jasa-jasa yang mereka perlukan;

3. berpartisipasi dalam proses pembangunan dan keputusan-keputusan yang mempengaruhi mereka (Sugarto, 2005).

Kemandirian adalah hakikat dari kemerdekaan, yaitu hak setiap bangsa untuk menentukan nasibnya sendiri dan menentukan apa yang terbaik bagi darinya (Kartasasmita, 1996). Kemandirian suatu negara dalam memenuhi kebutuhan rakyatnya menjadi indikator penting. Oleh karena itu, pembangunan sebagai usaha untuk mengisi kemerdekaan, haruslah pula merupakan upaya membangun kemandirian pangan. Kemandirian 
atau swasembada merupakan falsafah penting dalam falsafah pembangunan (Saptana et al., 2014).

Terdapat tiga konsep penting dalam pengembangan masyarakat, yaitu:

1. Konsep pengembangan masyarakat (Community Development/CD)

2. Pembangunan kapasitas (Capacity Building/CB)

3. Manajemen berbasis komunitas (Community Based Management/CBM).

Pengembangan masyarakat (CD) sebagai sebuah proses usaha bersama antara pemerintah dan masyarakat dalam upaya meningkatkan kesejahteraan sosial ekonomi masyarakat, sedangkan pembangunan kapasitas (CB) berperan sebagai instrumen atau alat yang mendukung penggunaan potensi dan kapasitas yang ada secara efisien, memperluas kondisi yang ada, dan membangkitkan potensi-potensi baru. Sementara itu, konsep manajemen berbasis komunitas (CMB) memberikan penekanan pada "komunitas atau masyarakat" yang menjadi pelaku utama.

\section{Keberadaan Desa Ardi Mulyo}

Desa Ardi Mulyo teletak di Kecamatan Tanjung Palas Utara, Kabupaten Bulungan, Kalimantan Utara. Batasbatas Desa Ardi Mulyo sebelah Utara berbatasan dengan Desa Sekatak/Panca Agung, sebelah Barat dengan Desa Panca Agung, sebelah Selatan dengan Desa Ruhui Rahayu, dan sebelah Timur dengan Desa Salimbatu. Program yang diunggulkan dalam PKM di desa Ardi Mulyo adalah pemanfaatan lahan untuk tanaman hidroponik.

1. Mengurai gergajen atau limbah kayu, ini adalah bahan dasar dalam penanaman sistem hidroponik.

2. Serbuk limbah kayu yang sudah diurai kemudian dicampur dengan tanah, ini dilakukan supaya bibit yang akan ditanam dapat hidup dan bertahan karena akar bibit tersebut dapat bertahan.

3. Setlah terurai dan tercampur serbuk kayu dan tanah, kemudian uraian campuran tersebut dimasukkan dalam demplot bahannya dari plastik. Bahan ini digunakan untuk memudahkan tanaman berkembang dan bertahan hdup dengan baik.

4. Langkah selanjutnya adalah mempersiapkan lahan pekarangan rumah yang tidak termanfaatkan dengan baik. Untuk menjaga tanaman hidroponik berkembang dan hidup dengan baik, maka yang dilakukan adalah membuat greenhouse sebagai pelindung tanaman dari binatang dan ancaman lainnya. Langkah selanjutnya adalah pembersihan lahan untuk persiapan pembuatan greenhouse.

5. Setelah pembuatan greenhouse selesai, maka langkah selanjutnya adalah meletakkan demplot yang sudah terisi campuran serbuk kayu dan tanah ke dalam greenhouse. Kemudian menanam bibit yang sudah tumbuh.

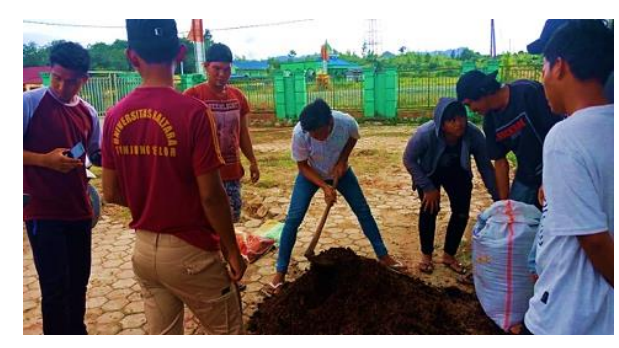

Gambar 1. Mengurai Limbah Kayu (serbuk kayu)

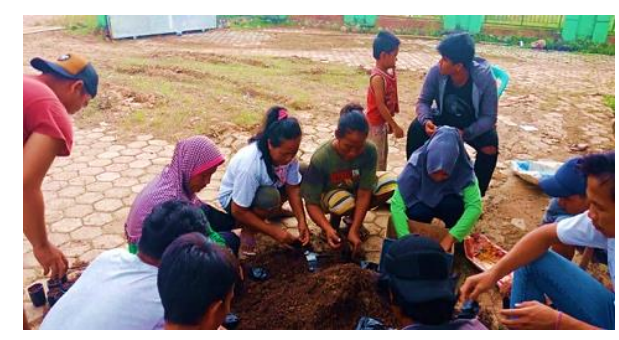

Gambar 2. Memasukkan limbah kayu pada demplot

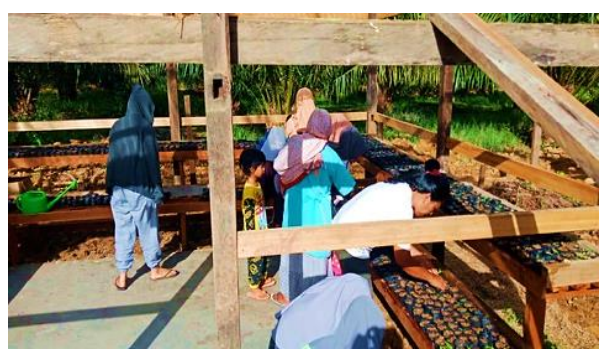

Gambar 3. Penanaman bibit sayuran pada demplot 


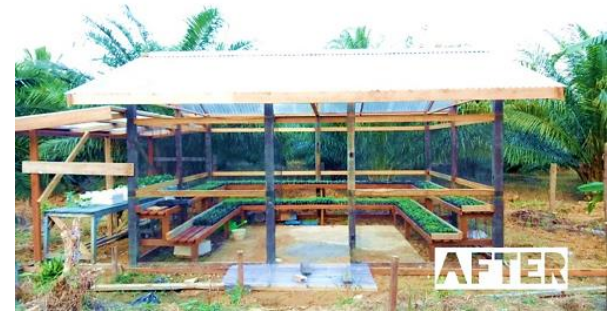

Gambar 4. Greenhouse berisi bibit sayuran

Diharapkan bahwa, lahan kosong yang tidak terpakai dapat dimanfaatkan dengan baik, gambar di atas menunjukkan bahwa kemandirian masyarakat Desa Ardi Mulyo dapat tercapai dalam memenuhi kebutuhan hidup sehari-hari khususnya pemenuhan kebutuhan sayuran, program ini dilakukan karena masyarakat Desa Ardi Mulyo dalam kehidupan sehari-hari tidak mudah untuk mendapatkan sayuran, karena tipologi masyarakat yang berorientasi pada tanaman padi dan sawit. Meskipun terdapat pasar di desa tersebut, tetapi tidak mudah untuk menjumpai penjual sayuran. Sehingga program ini sangat bermanfaat bagi masyarakat Desa Ardi Mulyo.

\section{Desa Panca Agung}

Desa panca agung merupakan salah satu desa yang ada di Kecamatan Tanjung Palas Utara Kabupaten Bulungan. Luas wilayah desa ini adalah 99,67 km2 atau 12,36\% dari luas wilayah kecamatan Tanjung Palas Utara. Jumlah penduduk desa panca agung adalah 2033 yang terkumpul dalam $571 \mathrm{KK}$. Untuk presentase jumlah penduduk, desa panca agung menempati urutan ke-3 dari 6 desa yang ada. Desa panca agung terbagi dalam tiga RW dan lima belas RT.

Program pelaksanaan kegiatan pengabdian kepada masyarakat yang dilakukan di desa panca agung adalah pengelolaan sampah menjadi bahan bakar. Pada dasarnya pengelolaan secara zero waste merupakan pengelolaan dengan melakukan pemilahan, pengomposan dan pengumpulan barang layak jual. Pemilahan sampah dalam rumah tangga harus didukung fasilitas pewadahan berupa tong sampah yang memadai. Tong sampah yang harus disediakan dalam rumah cukup dibagi untuk 2 jenis sampah yaitu sampah organik (basah) dan sampah anorganik (kering). Sampah yang telah terpilah menjadi sampah basah dan kering selanjutnya dilakukan pengelolaan yaitu pengomposan dan pengumpulan sampah layak jual. Pengomposan merupakan teknik untuk mengolah sampah organik yang berupa sampah sisa makanan, sisa potongan sayur dan buah atau sampah dapur dan sampah dari sapuan halaman rumah. Jika sampah organik rumah tangga dikelola secara mandiri (on site) dengan cara dikomposkan maka sampah anorganik harus dikelola dengan bantuan pihak ketiga (off site). Pihak ketiga yang dapat mendukung pengelolaan sampah anorganik rumah tangga adalah para pelaku usaha daur ulang informal antara lain pemulung, tukang loak, pengrajin produk daur ulang khusus untuk sampah plastik kemasan berlapis aluminium foil serta ada alternatif baru yaitu menabung sampah di bank sampah. Peningkatan jumlah penduduk dan laju pertumbuhan industri yang seakin pesat akan memberikan dampak pada jumlah sampah yang dihasilkan antara lain sampah plastik, kertas, produk kemasan yang mengandung B3 (Bahan Beracun Berbahaya). Jumlah dan jenis sampah, sangat tergantung dari gaya hidup dan jenis material yang kita konsumsi semakin meningkat perekonomian dalam rumah tangga maka semakin bervariasi jumlah sampah yang dihasilkan. Selain kondisi tersebut masih djumpai timbulan atau buangan sampah di sungai sehingga memberikan dampak negative pada lingkungan yang akhirnya menganggu kesehatan manusia.

Adanya UU No. 18/2008 tentang Pengelolaan sampah dengan maksimal. Adapun upaya pengelolaan sampah dapat dilakukan dengan cara Reuse, Reduce, dan Recycle (3R) adalah kegiatan memperlakukan sampah dengan 
cara, menggunakan kembali, mengurangi dan mendaur ulang.

1. Reuse (menggunakan kembali)

Penggunaan kembali sampah secara langsung, baik untuk fungsi yang sama maupun fungsi lain.

2. Reduce (mengurangi)

Mengurangi segala sesuatu yang menyebabkan timbulnya sampah.

3. Recycle (mendaur ulang)

Memanfaatkan kembali sampah setelah mengalami proses pengolahan.

Timbunan sampah pada rempat pembuangan sampah sementara maupun tempat pembuangan akhir akan menghasilkan lindi. Leachate atau lindi adalah limbah cair yang timbul akibat masuknya air eksternal ke dalam timbunan sampah, melarutkan dan membilas materimateri terlarut, termasukjuga materi organik hasil proses dekomposisi biologis. Dari sana dapat diramalkan bahwa kuantitas dan kualitas lindi akan sangat bervariasi dan berfluktuasi. Leachate atau lindi yang tidak ditangani dengan baik yaitu tanpa melalui pengolahan dapat memberikan dampak negatif pada lingkungan antara lain timbulnya bau sehingga menguranggi estetika, timbulnya penyakit. Vektor atau pembawa penyakit yang ditimbulkan dari tempat sampah adalah tipus, disentri dengan vektor pembawa penyakit adalah lalat, kecoa, tikus dan lain sebagainya.

Berdasarkan potret pengelolaan sampah yang ada sekarang ini, beberapa indikasi permasalahan muncul yang disebabkan oleh:

1. Sampah yang bercampur antara basah dan kering, sehingga sangat sulit untuk dimanfaatkan kembali. Meskipun sampah basah bisa dibuat kompos, tetapi jika telah bercampur dengan sampah berbahaya seperti batu baterai, pembalut wanita, atau jenis-jenis kimia lainnya maka kualitas kompos yang dihasilkan akan rendah.
2. Akibat tidak adanya partisipasi masyarakat maka petugas kebersihan yang dikerahkan oleh pemerintah kota menjadi tidak berimbang antara jumlah petugas dengan jumlah sampah yang harus ditangani.

3. Kapasitas TPA yang terbatas, jumlah sampah setiap hari terus menerus masuk ke TPA, hanya sebagian kecil saja yang dapat direduksi oleh pemulung. Pada suatu saat TPA tidak sanggup lagi menampung sampah kota yang dibuang oleh masyarakat. Ketika TPA tidak beroperasi dalam beberapa hari saja, maka sampah kota akan menumpuk dan tersebar dimanamana.

4. Biaya operasional pengangkutan sampah dari TPS menuju TPA yang terus menerus meningkat seiring dengan kenaikan harga bahan bakar dan ditambah lagi perlunya biaya operasional untuk merawat armada-armada pengangkut sampah.

5. Tidak ada masyarakat yang mau jika lingkungannya dijadikan sebagai tempat pembuangan sampah. Ditambah lagi pada era otonomi daerah kesulitan mencari lahan di luar wilayah administrasinya.

Sebelum melaksanakan kegiatan PKM, maka ada beberapa bahan yang perlu disiapkan, diantaranya adalah ember yang terbuat dari seng atau bekas cat besar. Kemudian toples yang terbuat dari seng atau bisa memanfaatkan kaleng biskuit, dan bahan ke-3 adalah paralon besi stainless, karena resiko tinggi yang dapat ditimbulkan dari penyulingan maka bahan pipa stainless lebih membantu. Adapaun bahan baku utama adalah sampah yang berbentuk atau terbuat dari plastik, seperti botol air minum, gelas air minum dan plastik yang lainnya.

Langkah pertama adalah meyiapkan peralatan yang dibutuhkan seperti ember besar yang terbuat dari seng atau sejenisnya, sebagai tempat memanaskan sampah plastik. Kemudian alat yang lain yakni toples atau blak 
bekas wafer sebagai tempat hasil penyulingan atau pembakaran. Terlebih yang tidak bisa dilupakan adalah paralon stainless.

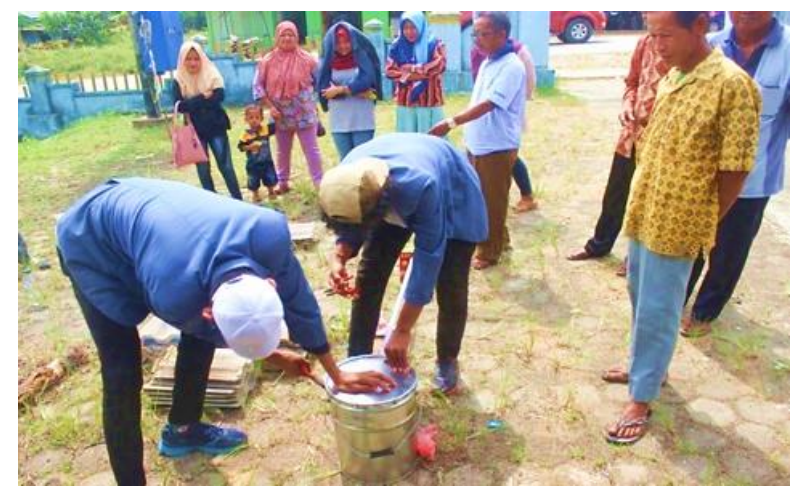

Gambar 5. Membuat pola pada ember

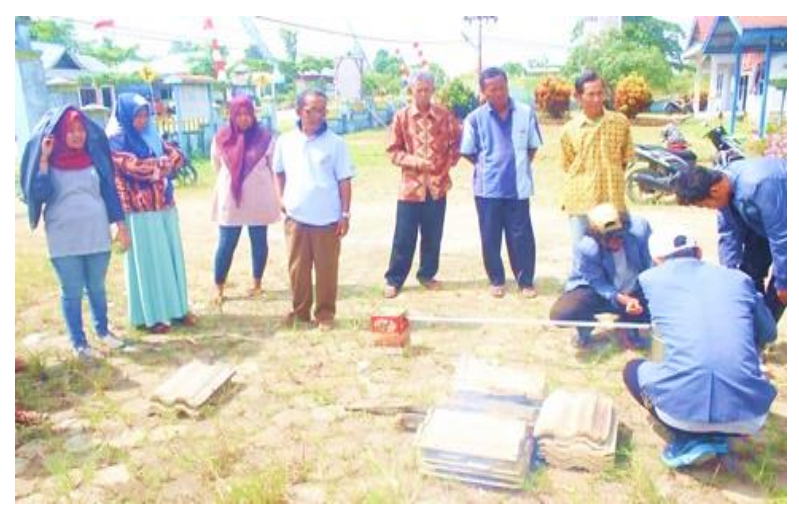

Gambar 6. Proses penyulingan

Terlihat dari gambar, yakni pemasangan alat-alat penyulingan yang harus dirangkai dan disusun dengan baik dan benar, karena dampak atau jika mengalami kegagalan penyusunan dan bocor maka dapat berakibat buruk bagi manusia dan sekitar, jadi perlu ketelitian dan kejelian dalam merangkai.

Untuk bahan pembakar, pelaksana kegiatan lebih cenderung memilih serabut kelapa dari pada bahan kayu atau material lainnya, karena serabut kepala mudah didapat di desa panca agung dari pada material yang lain. Selain mudah didapat, serabut kelapa juga mudah terbakar sehingga tidak membutuhkan minyak tanah sebagai perangsang api. Ada banyak manfaat yang didapat dari serabut kelapa, yakni:

1. Serabut kelapa sebagai bahan dasar pupuk organik
Sabut kelapa memiliki usur hara dan juga kandungan mineral yang cukup tinggi yang baik untuk pertumbuhan tanaman, maka sabut kelapa sangat cocok untuk dibuat menjadi pupuk organik. Apalagi pupuk organik yang dibuat dari sabut kelapa menyimpan 60\% air lebih banyak dibanding pupuk biasa. Jadi pupuk organik dari sabut kelapa cocok didaerah yang curah hujannya rendah atau daerah yang sedang dilanda kekeringan.

2. Serabut kelapa sebagai penetralisir bau semen pada kolam yang baru dibuat

Kolam ikan yang baru dibuat sering kali meninggalkan bau semen yang kurang sedap. Hal ini tentunya membuat budidaya ikan memjadi terhambat. Salah satu cara alami yang ampuh menghilangkan bau semen pada kolam yang baru dibuat, yaitu menggunakan sabut kelapa. Caranya sangat mudah, cukup dengan menaburkan sabut kelapa atau bisa dicampur dengan dedaunan yang mudah membusuk dan biarkan selama 1 sampai 2 minggu. Air akan berwarna kecoklatan hingga warna kehijauan, warna air yang berubah tersebut menandakan kolam sudah siap untuk media pembudidayaan ikan.

3. Serabut kelapa sebagai media pembakar pengganti minyak fosil atau juga kertas. Manfaat umum dari sabut kelapa adalah seringnya digunakan para pengusaha arang dari tempurung kelapa yang menjadikan sabut kelapa sebagi media pembakaran. Selain itu sabut kelapa sebagai media pembakaran juga sering digunakan restoran -restoran tradisional yang masih menggunakan tunggu trasional untuk memasak. Bahkan industri-industri seperti pembuatan keramik dan genteng juga menggunakan sabut kelapa. Ini karena sabut kelapa yang sudah kering mudah terbakar dan juga menghasilkan api yang stabil 
4. Serabut kelapa sebagai penyaring air sederhana. Salah satu manfat penting dari sabut kelapa yaitu sebagai alat untuk membantu menyaring air secara sederhana. Struktur sabut kelapa yang berserat dapat membantu proses penyaringan air. Lalu bagaimana caranya untuk proses penyaring? berikut kami sampaikan cara simpel dan sederhana. Langkahnya adalah yaitu pertama sabut kelapa harus dikupas terlebih dahulu dari kulit arinya kemudian baru dapat digunakan untuk menyaring air. Air yang melewati saringan sabut kelapa akan terpisah sampah atau kotoran sehingga akan didapat air yang semakin jernih. Proses ini harus dilakukan berkalikali agar mendapat air jernih yang maksimal.

5. Serabut kelapa sebagai pengganti kayu untuk memasak. Sabut kelapa ini sangat mudah ditemukan, biasanya setelah meraka ambil kelapanya, kemudian sabutnya dijemur dan setelah kering dipakai untuk masak di dalam tungku tradisional atau tumpukan batu bata. Salah satu kelebihan sabut kelapa sebaga pengganti kayu bakar adalah karena sabut kelapa kering, maka darinya memiliki sifat yang mudah terbakar, serta dapat menghasilkan apinya yang cukup stabil. Tentu dari proses ini banyak asap yang dihasilkan, tetapi jangan salah, biasanya masakan yang dimasak dengan cara alami begini, serasa sangaat nikmat. Serabut kelapa sebagai penahan erosi pada tebing

6. Media sabut kelapa yang dipakai dalam teknik ini adalah dengan cara membuatnnya menjadi jaring sabut kelapa atau sering disebut dengan cocomesh. Pembuatan cocomesh ini diawali dengan cara sabut kelapa dibuatnya menjadi tali sabut. Kemudian proses selanjutnya adalah mengayam tali tersebut dengan ukuran mash atau jarak tertentu.

Ukuran cocomesh umumnya adalah $2 \times 25$ meter atau juga bisa 1,2 $\times 15$ meter, sangat bergantung kepada kondisi kebutuhan. Dan jarak antar talinya bisa mulai dari $2 \times 2$ $\mathrm{cm}, 3 \times 3 \mathrm{~cm}$ dan $4 \times 4 \mathrm{~cm}$. Penggunaan cocomesh ini sudah mulai sangat familiar di kalangan para reklamator tambang. Karena terbukti sangat efektif untuk menahan erosi bekas tambang, juga mampu menghijaukan kembali area bekas tambang yang dipadukan dengan penumbuhan cover crop, atau biji-bijian penutup lahan. Ketika cover crop yang disebar pada cocomesh sudah tumbuh, maka langkah selanjutnya bisa dilakukan penanaman mengunakan tanaman keras.

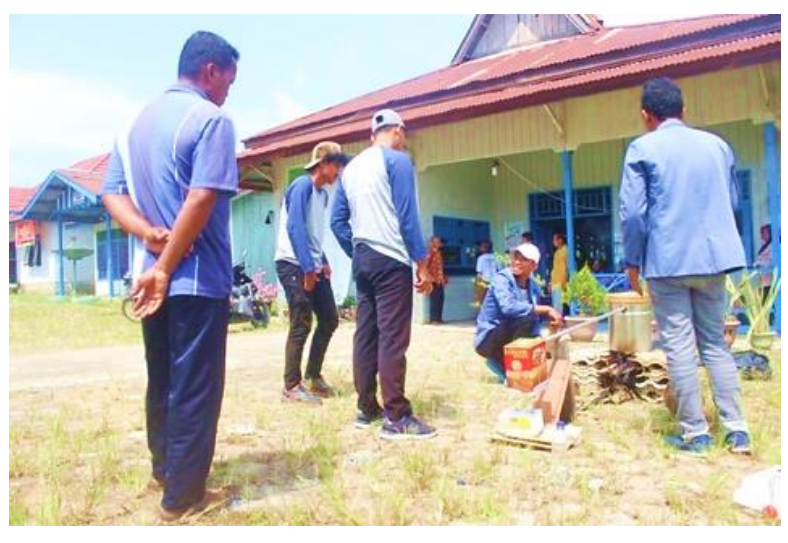

Gambar 7. Proses pembakaran penyulingan sampah plastik menjadi minyak tanah

\section{KESIMPULAN}

Terlihat bahwa untuk menghasilkan sayuran dapat mudah dilakukan oleh masyarakat desa ardi mulyo dengan memanfatkan lahan kosong dan proses pembuatan tanaman hidroponik sangat mudah, sehingga masyarakat desa ardi mulyo sangat terbantukan dengan program tersebut. Kemudian, program yang dilaksanakan di desa panca agung juga tidak kalah berkualitasnya, yakni penyulingan sampah plastik menjadi bahan bakan rumah tangga. Mesipun pada pelaksanaan kegiatan ini dibutuhkan bahan-bahan yang cukup malah khususnya paralon yang terbuat dari besi atau bahan stainlis, namun memiliki dampak yang baik bagi masyarakat, yakni aman dan tidak mudah bocor. Pelaksanaan kegiatan serupa perlu dilaksanakan di desa-desa binaan Universitas Borneo Tarakan, karena 
desa-desa binaan harus merubah kondisi desanya selain mengandalkan dari dana desa. Kegiatan yang dilaksanakan di desa ardi mulyo dan desa panca agung merupakan kegiatan yang dapat meningkatkan status masyarakat, sehingga dapat menumbuhkan kemandirian pada masyarakat dan berdampak pada kemandirian desa.

\section{UCAPAN TERIMA KASIH}

Terima kasih kami ucapkan kepada Universitas Borneo Tarakan yang telah memberi suporting dana kegiatan PKM yang terintegrasi dengan KKN.

\section{REFERENSI}

Ariyani, N.I., Nurcahyono, O.H. 2014. Digitalisasi Pasar Tradisional: Perspektif Teori Perubahan Sosial. Jurnal Analisa Sosiologi. 3(1):1-12. https://doi.org/10.20961/jas.v3i1.17442

Badan Pusat Statistik Kabupaten Bulungan. 2020. Kecamatan Tanjung Palas Utara Dalam Angka 2020. Kabupaten Bulungan: Badan Pusat Statistik Kabupaten Bulungan. https://bulungankab.bps.go.id/publication/ 2020/09/28/00fec2f852cefe39f4ad98fa/keca matan-tanjung-palas-utara-dalam-angka2020.html

Baridi, L., Zein, M., Hudri, M. 2007. Zakat dan Wirausaha. Jakarta: CED (Center for Enterprenership Development).

Cahyono, A.S. 2016. Pengaruh Media Sosial Terhadap Perubahan Sosial Masyarakat Di Indonesia. Publiciana: Jurnal Ilmu Sosial dan Ilmu Politik. 9(1):140-157.

Helmi, M. 2015. Konsep Keadilan Dalam Filsafat Hukum Dan Filsafat Hukum Islam. Mazahib: Jurnal Pemikiran Hukum Islam. 14(2):133-144. https://doi.org/10.21093/mj.v14i2.342

Kartasasmita, G. 1996. Pembangunan untuk Rakyat: Memadukan Pertumbuhan dan Pemerataan. Jakarta: CIDES.

Nasdim, F.T. 2014. Pengembangan Masyarakat. Jakarta: Yayasan Pustaka Obor Indonesia.
Saptana, Sejati, W.K., Rusastra, I.W. 2014. Kemandirian Pangan Berbasis Pengembangan Masyarakat: Pelajaran Dari Program PIDRA, SPFS, Dan Desa Mapan Di Nusa Tenggara Timur Dan Jawa Barat. Analisis Kebijakan Pertanian. 12(2):119-141.

http:/ /dx.doi.org/10.21082/akp.v12n2.2014.1 19-141

Sugarto, E. 2005. Membangun Masyarakat Memberdayakan Rakayat Kajian Strategis Pembangunan Kesejahteraan Sosial Dan Pekerja Sosial. Bandung: Ravika Adimatama.

Suradi, S. 2013. Perubahan Sosial Dan Ketahanan Keluarga: Meretas Kebijakan Berbasis Kekuatan Lokal. Sosio Informa. 18(2):83-94. https://doi.org/10.33007/inf.v18i2.74

Susilowati, S.H., Maulana, M. 2012. Luas Lahan Usaha Tani Dan Kesejateraan Petani: Eksistensi Petani Gurem Dan Urgensi Kebijakan Reforma Agraria. Analisis Kebijakan Pertanian. 10(1):17-30.

http://dx.doi.org/10.21082/akp.v10n1.2012.1 7-30

Yusup, Y., Giyarsih, S.R. Dampak Transmigrasi Terhadap Tingkat Kesejahteraan Warga Transmigran Di Desa Tanjung Kukuh Kecamatan Semendawai Barat Kabuapaten Ogan Komering Ulu. Jurnal Bumi Indonesia. 4(4):1-11. 